\title{
PENGARUH PEMBERIAN REBUSAN DAUN SELEDRI (Apium Graveolens $L$ ) TERHADAP TEKANAN DARAH PADA WANITA MENOPAUSE DENGAN HIPERTENSI
}

\section{DIAH EVAWANNA ANUHGERA ${ }^{1}$, RIZKY YOLANDA ${ }^{2}$, RIRIS SITORUS ${ }^{3}$, NIKMAH JALILAH RITONGA4, DAMAYANTI ${ }^{5}$}

\author{
1,3,4,5 INSTITUT KESEHATAN MEDISTRA LUBUK PAKAM \\ ${ }^{2}$ Alumni S1 Kebidanan, Institut Kesehatan Medistra Lubuk Pakam \\ Jl. Jendral Sudirman no 38 Lubuk Pakam \\ e-mail :diah.evawanna@gmail.com
}

DOI : $10.35451 / j k k . v 3 i 1.502$

\begin{abstract}
Woman menopause in hypertension is often associated with increase vascularity and physiological changes during menopause. This study aims to examine the effect of celery leaf stew on blood pressure levels in menopausal woman in hypertension. This study was a quasy experiment with pretestposttest control group design, conducted in the Sidodadi Village District Beringin, Deli Serdang on Januari to March 2020. There were 28 participants selected using purposive sampling, with 14 assigned in the experimental and control group. Data were analyzed using paired t-test and unpaired t-test. There were statistically significance difference of blood pressure levels before and after intervention in the experiment group with $p$ value sitolic level 0.000 dan diastolic level $0.001(<0.05)$. Celery leaf stew has a significant effect in reducing blood pressure level in menopausal woman in hypertension. This intervention could be applied as an alternative theraphy in treating menopausal woman in hypertension.
\end{abstract}

Keywords: celery, blood pressure, hypertension, menopause

\section{Pendahuluan}

Tekanan darah yang tinggi sering dikaitkan dengan peningkatan vascular dan mortalitas. Sebuah meta-analisis terbaru dari model prediksi risiko untuk hipertensi menemukan bahwa usia, jenis kelamin, indeks massa tubuh (BMI), tekanan darah dasar, dan merokok adalah prediktor paling umum dari tekanan darah tinggi. Saat ini hipertensi masih menjadi penyebab kematian yang sangat berbahaya karena merupakan kelainan kronis tanpa gejala yang secara diam-diam merusak pembuluh darah, jantung, otak, dan ginjal jika tidak terdeteksi dan tidak diobati (Moghadam, 2013).
Menurut Organisasi Kesehatan Dunia, prevalensi hipertensi secara keseluruhan pada tahun 2000 adalah sekitar 26,4\%. Populasi dunia dengan hipertensi akan meningkat sekitar $60 \% .1,56$ miliar pada tahun 2025. Berdasarkan data Riskesdas 2018, prevalensi hipertensi di Indonesia adalah $34,1 \%$, hal ini menunjukkan kejadian hipertensi mengalami peningkatan dibandingkan denga-n tahun sebelumnya pada tahun 2013 prevalensi hipertensi di Indonesia sebesar 25,8\% (Kemenkes, 2018)

Menurut Zhou et al 2015, hubungan linier antara tekanan darah dan risiko kejadian kardiovaskular telah diidentifikasi bahwa hipertensi merupakan faktor risiko utama penyakit 
kardiovaskular (CVD). Studi epidemiologi telah menunjukkan hubungan erat antara penurunan tekanan darah dan risiko kardiovaskular, yang menunjukkan bahwa penurunan tekanan darah sistolik tinggi (Zhou, 2015).

$$
\text { Menopause pada wanita }
$$

berhubungan dengan habisnya folikel ovarium yang disertai dengan perubahan fisik dan psikologis. Salah satu penyakit penyerta yang sering dialami wanita menopause adalah hipertensi ( $\mathrm{Pu}, \mathrm{D}$, 2017). Wanita menopause di usia 45-55 tahun beresiko lebih tinggi mengalami hipertensi dibandikan wanita pada masa premenopause dan perimenopause (Zhou et al, 2014). Hipertensi pada siklus reproduksi sering menjadi polemik yang mengganggu terutama saat kehamilan, persalinan, nifas dan masa premenopause hingga menopause (Yusuf, N., Anugerah, D. E., \& Adiani, F. (2017)

Diet, strategi gaya hidup, dan penggunaan nutraceutical memiliki bukti yang berkembang untuk mendukung kemanjurannya sebagai strategi pengendalian tekanan darah. Beberapa studi cross-sectional dan longitudinal menyatakan bahwa wanita menopause memiliki resiko besar untuk mengalami hipertensi dibandingkan wanita pramenopause trelepas dari usia dan indeks massa tubuh (BMI) (Santoro, N., \& Johnson, J. (2019). Pengendalian hipertensi telah terbukti mengurangi risiko stroke atau kematian di usia lanjut maupun di orang yang lebih muda dan pada mereka dengan hipertensi stadium I dan II (atau ringan) (Bonilla Ocampo et al, 2018)

Anti hipertensi konvensional sering dikaitkan dengan banyak efek samping. Sekitar $80 \%$ populasi dunia menggunakan obat-obatan herbal untuk perawatan kesehatan primer karena lebih mudah diterima dan memiliki efek samping yang lebih rendah. Dalam tiga puluh tahun terakhir, banyak upaya yang dilakukan untuk meneliti tanaman asli dengan sifat hipotensi dan antihipertensi (Bomfim GHS, et al, 2019).
Pengobatan farmakologi yang digunakan untuk hipertensi yaitu penghambat beta, penghambat enzim pengubah angiotensin (ACE), diuretik, penghambat alfa, dan penghambat saluran kalsium. Salah satu efek samping diuretik adalah simpanan kalium tubuh yang dikeluarkan tubuh melalui urin bersama dengan natrium. Hilangnya kalium ini dapat menyebabkan kram otot dan dalam kasus ekstrim, kematian (Sohrabi, $\mathrm{F}$ et al, 2020). Beta blocker mengurangi kekuatan pemompaan jantung. Efek samping yang paling umum dari penghambat ACE termasuk batuk, pusing, sakit kepala, tekanan darah rendah dan kelelahan. Efek samping saluran kalsium yang umum termasuk pembengkakan, cairan di paru-paru, sakit kepala, kelelahan, dan palpitasi (Anjos, P.J., et al 2013)

Pengobatan hipertensi dapat diberikan secara farmakologis dan non farmakologis. Pengobatan non farmakologis menggunakan bahan herbal atau tradisional (CAM). Upaya peningkatan keamanan dan khasiat obat tradisional juga didukung oleh WHO. Hal ini dikarenakan efek samping penggunaan obat tradisional relatif lebih sedikit dibandingkan dengan pengobatan modern (Saputra O, Fitria T, 2016).

Peneliti termotivasi untuk menemukan beberapa tanaman herbal tradisional atau bahan aktif dengan efek samping dan toksisitas yang lebih rendah daripada obat kimia untuk mengendalikan hipertensi. Indonesia memiliki banyak sekali tanaman obat asli yang telah digunakan selama berabad-abad untuk mengobati penyakit. Banyak penelitian yang telah melakukan penelitian mengenai obat herbal dalam mengatasi hipertensi yaitu dengan konsumsi teh hijau, bawang putih, Nigella Sativa, dan lada (Bogdanski et al., 2012).

Pengobatan hipertensi secara non farmakologi juga dapat diberikan melalui konsumsi seledri (Apium Graveolens $L$ ). Daun seledri berbentuk menyirip sepanjang 3-6 cm dan lebar 2$4 \mathrm{~cm}$. Seledri memiliki banyak kandungan, salah satunya n- 
butylphthalide (NBP) bersama dengan sedanolide yang masing-masing memberikan aroma dan rasa seledri. Beberapa penelitian menunjukkan NBP yang di ekstrak dari tanaman herbal lain memiliki efek antihipertensi dengan percobaan pada hewan (Zhu et al., 2015).

Penelitian lain telah menunjukkan bahwa seledri dan bahan aktifnya memiliki sifat terapeutik yang berbeda seperti aktivitas hepatoprotektif, peningkatan kognitif, efek pelindung saraf, anti aktivitas peradangan dan sifat antioksidan. Konsumsi seledri mengakibatkan vasodiltasi (pelebaran pembuluh darah) dengan cara relaksasi pada sel otot polos di dinding pembuluh darah sehingga mengakibatkan penurunan pada tekanan darah (Niaz et al, 2013).

Penelitian sebelumnya menyatakan bahwa dengan ekstrak biji seledri efektif menurunkan tekanan darah sistolik (SBP) sebesar $4,6 \mathrm{mmHg}$ dan tekanan darah diastolic (DBP) 4,5 $\mathrm{mmHg}$ per minggu. Seledri dikonsumsi selama 6 minggu dan terjadi penurunan pada SBP dan DBP dibandingkan kelompok kontrol dengan nilai signifikansi $p=0,005$ (Moghadam et al, 2013).

Berdasarkan survey awal yang dilakukan peneliti di Desa Sidodadi Ramunia Kecamatan Beringin Kabupaten Deli Serdang data jumlah menopause yang menderita hipertensi sebanyak 56 orang. Berdasarkan survey awal diatas peneliti tertarik meneliti dengan judul : "Pengaruh Pemberian Rebusan Daun Seledri Terhadap Penurunan Tekanan Darah Pada Wanita Menopause Penderita Hipertensi". Tujuan penelitian ini adalah untuk mengetahui pengaruh pemberian rebusan daun seledri terhadap penurunan tekanan darah pada wanita menopause penderita hipertensi.

\section{METODE}

Jenis penelitian ini adalah kuasi eksperimen dengan pretest-posttest control group design. Lokasi penelitian ini berada di Desa Sidodadi Ramunia Kecamatan Beringin Kabupaten Deli
Serdang pada Januari sampai Maret 2020.

Sampel pada penelitian ini adalah seluruh ibu menopause yang mengalami hipertensi tingkat I dan II sebanyak 28 oran. Pada penelitian ini sampel terbagi menjadi dua kelompok yaitu kelompok intervensi (diberikan pemberian rebusan daun seledri) sebanyak 14 orang dan kelompok kontrol sebanyak 14 orang dengan menggunakan teknik sampel purposive sampling.

Kriteria inklusi pada penelitian ini adalah ibu berusia 50-70 tahun, bersedia menjadi respnden dengan menandatangani informed consent, konsumsi obat anti hipertensi, tidak merokok dan mengkonsumsi alkohol, BMI < 25. Kriteria eksklusi yaitu ibu yang memiliki komplikasi penyakit penyerta, mengkonsumsi makanan yang menurunkan tekanan darah.

Pada kelompok intervensi dan kontrol dilakukan penilaian awal tekanan daraha pada hari pertama. Pada responden dengan kelompok intervensi diberikan rebusan daun seledri sebanyak $200 \mathrm{ml}$ di sore hari selama 1 minggu dan obat anti hipertensi sedangkan pada kelompok kontrol hanya memperoleh obat anti hipertensi selama 1 minggu. Pada hari ke 7 dilakukan penilaian tekanan darah lagi pada kedua kelompok. Pada penelitian ini, peneliti dibantu enumerator di lapangan untuk memantau makanan yang dikonsumsi selama penelitian. Prosedur pembuatan rebusan daun seledri yaitu menggunakan 8 tangkai daun seledri dan direbus dengan air sebanyak $400 \mathrm{ml}$ selama 10 menit lalu dikonsumsi oleh responden penelitian sebanyak $200 \mathrm{ml}$.

Instrumen penelitian adalah lembar observasi penilaian tekanan darah untuk pemberian rebusan daun seledri, pemeriksaan tekanan darah serta food recall untuk menilai makanan yang dikonsumsi oleh responden selama penelitian, tensimeter air raksa dan gelas ukur. Analisis data menggunakan uji statistik pair t-test dan unpaired $t$ test 


\section{HASIL}

Tabel 1 menunjukkan bahwa rerata tekanan darah sistolik sebelum pemberian rebusan daun seledri adalah $150.40 \mathrm{mmHg}$, sedangkan rerata tekanan darah sistolik sesudah pemberian rebusan daun seledri sebesar $121.93 \mathrm{mmHg}$. Selisih rerata tekanan darah sistolik sebelum dan setelah diberikan pemberian rebusan daun seledri sebanyak $28.47 \mathrm{mmHg}$.
Rerata tekanan darah diastolik sebelum pemberian rebusan daun seledri sebesar $111 \mathrm{mmHg}$, sedangkan rerata tekanan darah diastolik sesudah pemberian rebusan daun seledri sebesar $83 \mathrm{mmHg}$. . Selisih rerata tekanan darah diastolik sebelum dan setelah diberikan pemberian rebusan daun seledri sebanyak $28 \mathrm{mmHg}$.

Tabel 1.Distribusi Tekanan Darah Sebelum dan Sesudah Intervensi Pada Kelompok Intervensi

\begin{tabular}{|c|c|c|c|c|c|c|}
\hline \multirow[t]{2}{*}{ Responden } & \multicolumn{2}{|c|}{ Tekanan Darah Sistolik } & \multirow[t]{2}{*}{ Selisih } & \multicolumn{2}{|c|}{ Tekanan Darah Diastol } & \multirow[t]{2}{*}{ Selisih } \\
\hline & Sebelum & Setelah & & Sebelum & Setelah & \\
\hline 1 & 150 & 130 & 20 & 110 & 90 & 20 \\
\hline 2 & 146 & 114 & 32 & 100 & 80 & 20 \\
\hline 3 & 160 & 120 & 40 & 125 & 80 & 45 \\
\hline 4 & 150 & 120 & 30 & 120 & 70 & 50 \\
\hline 5 & 155 & 130 & 25 & 120 & 100 & 20 \\
\hline 6 & 140 & 120 & 20 & 110 & 75 & 35 \\
\hline 7 & 140 & 115 & 25 & 100 & 80 & 20 \\
\hline 8 & 150 & 125 & 25 & 110 & 80 & 30 \\
\hline 9 & 160 & 120 & 40 & 110 & 90 & 20 \\
\hline 10 & 150 & 120 & 30 & 120 & 90 & 30 \\
\hline 11 & 140 & 115 & 25 & 100 & 70 & 30 \\
\hline 12 & 160 & 135 & 25 & 110 & 80 & 30 \\
\hline 13 & 150 & 130 & 20 & 110 & 90 & 20 \\
\hline 14 & 146 & 114 & 32 & 100 & 80 & 20 \\
\hline Mean & 150.40 & 121.93 & 28.47 & 111 & 83 & 28 \\
\hline
\end{tabular}

Tabel 2 menunjukkan bahwa rerata tekanan darah sistolik pada kondisi awal (pretest) sebesar 152.50 $\mathrm{mmHg}$, sedangkan rerata tekanan darah sistolik pada posttest sebesar 142.86 $\mathrm{mmHg}$. Selisih rerata tekanan darah sistolik pada kelompok kontrol sebanyak $9.64 \mathrm{mmHg}$. Rerata tekanan darah diastole pada kondisi awal pretest sebesar $115.43 \mathrm{mmHg}$, sedangkan rerata tekanan darah diastol pada posttest sebesar $105.57 \mathrm{mmHg}$. . Selisih rerata tekanan darah diastolik sebelum dan setelah diberikan pemberian rebusan daun seledri sebanyak 9.86 $\mathrm{mmHg}$.
Pada tabel 3 hasil uji statistik rerata tekanan darah sebelum dan sesudah pada kelompok intervensi menunjukkan nilai $p$ sistol sebesar 0.000 dan $p$ diastol 0.001 artinya terdapat penurunan yang signifikan sebelum dan sesudah pemberian rebusan daun seledri. Sedangkan pada kelompok kontrol, hasil uji statistik rerata tekanan darah sebelum dan sesudah pada kelompok kontrol menunjukkan nilai $p$ sistol sebesar 0.003 dan $p$ diastol 0.010 artinya terdapat penurunan yang signifikan sebelum dan sesudah pada kondisi awal dan akhir. 
Tabel 2.Distribusi Tekanan Darah Sebelum dan Sesudah Intervensi pada Kelompok Kontrol

\begin{tabular}{|c|c|c|c|c|c|c|}
\hline \multirow[t]{2}{*}{ Responden } & \multicolumn{2}{|c|}{ Tekanan Darah Sistolik } & \multirow[t]{2}{*}{ Selisih } & \multicolumn{2}{|c|}{ Tekanan Darah Diastol } & \multirow[t]{2}{*}{ Selisih } \\
\hline & Sebelum & Setelah & & Sebelum & Setelah & \\
\hline 1 & 140 & 130 & 10 & 100 & 80 & 20 \\
\hline 2 & 150 & 120 & 30 & 130 & 90 & 40 \\
\hline 3 & 140 & 120 & 20 & 80 & 78 & 2 \\
\hline 4 & 160 & 150 & 10 & 130 & 110 & 20 \\
\hline 5 & 160 & 150 & 15 & 120 & 120 & 0 \\
\hline 6 & 150 & 150 & 0 & 120 & 110 & 10 \\
\hline 7 & 155 & 130 & 20 & 120 & 100 & 10 \\
\hline 8 & 140 & 140 & 0 & 110 & 110 & 0 \\
\hline 9 & 160 & 150 & 10 & 110 & 100 & 10 \\
\hline 10 & 150 & 150 & 0 & 126 & 120 & 6 \\
\hline 11 & 170 & 160 & 10 & 130 & 120 & 10 \\
\hline 12 & 140 & 140 & 0 & 110 & 110 & 0 \\
\hline 13 & 150 & 150 & 0 & 100 & 110 & 20 \\
\hline 14 & 170 & 160 & 10 & 130 & 120 & 10 \\
\hline Mean & 152.50 & 142.86 & 9.64 & 115.43 & 105.57 & 9.86 \\
\hline
\end{tabular}

Tabel 3. Perbedaan Rerata Tekanan Darah Sebelum dan SesudahPemberian Rebusan Seledri pada Kelompok Intervensi dan Kontrol

\begin{tabular}{|c|c|c|c|c|}
\hline \multirow[t]{2}{*}{ Kelompok } & \multirow[t]{2}{*}{ Variabel } & Pretest & Posttest & \multirow{2}{*}{$\mathrm{P}$} \\
\hline & & Mean \pm SD & Mean \pm SD & \\
\hline \multirow[t]{2}{*}{ Intervensi } & Sistol & $151.14 \pm 7.58$ & $122.79 \pm 6.51$ & 0.000 \\
\hline & Diastol & $98.57 \pm 16.91$ & $83.93 \pm 11.12$ & 0.001 \\
\hline \multirow[t]{2}{*}{ Kontrol } & Sistol & $152.50 \pm 10.51$ & $142.86 \pm 13.26$ & 0.003 \\
\hline & Diastol & $115.43 \pm 14.78$ & $105.57 \pm 14.27$ & 0.010 \\
\hline
\end{tabular}

Berdasarkan tabel 4 menunjukkan bahwa rerata tekanan darah sistol setelah dilakukan intervensi $122.79 \pm 6.51$ lebih rendah dibandingkan kelompok kontrol 142.86 13.26 dengan nilai $\mathrm{p}$ sebesar 0.00 , artinya terdapat perbedaan rerata tekanan darah sistol yang signifikan antara kelompok intervensi dan kontrol. Rerata tekanan darah diastol setelah dilakukan intervensi $83.93 \pm 11.12$ lebih rendah dibandingkan kelompok kontrol $105.57 \pm 14.27$.

Tabel 4. Perbedaan Rerata Tekanan Darah Sesudah Pemberian Rebusan Seledri pada Kelompok Intervensi dan Kontrol

\begin{tabular}{cccc}
\hline Variabel & Variabel & Mean \pm SD & $\mathrm{P}$ \\
\hline \multirow{2}{*}{ Sistol } & Intervensi & $122.79 \pm 6.51$ & 0.000 \\
\cline { 2 - 3 } & Kontrol & $142.86 \pm 13.26$ & \\
\hline \multirow{2}{*}{ Diastol } & Intervensi & $83.93 \pm 11.12$ & 0.000 \\
\cline { 2 - 4 } & Kontrol & $105.57 \pm 14.27$ & \\
\hline
\end{tabular}




\section{PEMBAHASAN}

Hasil penelitian ini menunjukkan bahwa ada perubahan penurunan tekanan darah melalui pemberian rebusan daun seledri dengan selisih peurunan tekanan darah $28,47 \mathrm{mmHg}$. Pemberian rebusan daun seledri diberikan sebanyak 1 kali 1 hari tepatnya di sore hari pada interval waktu 14.00-16.00 WIB sebanyak 200 cc. Proses pengukuran tekanan darah diukur setiap hari terhadap semua responden dan memantaunya di lembar observasi serta melakukan pencatatan terhadap makanan apa saja yang dikonsumsi oleh responden selama menjalani penelitian ini.

Hasil penelitian ini sesuai dengan Arie N.M 2014 yang menyatakan dengan pemberian rebusan seledri kepada lansia penderita hipertensi dapat menurunkan tekanan darah sebesar 6.39\%. Pada Oktavia 2017, pemberian air rebusan seledri dapat menurunkan tekanan darah sistolik sebesar 17.64 sedangkan diastoli sebesar $18.18 \%$.

Hipertensi merupakan faktor risiko yang signifikan untuk morbiditas dan mortalitas di seluruh dunia. Perhatian utama adalah bahwa pengobatan hipertensi pada sejumlah besar pasien dengan hipertensi tidak memuaskan, dan kepatuhan dengan agen antihipertensi biasanya buruk (Zhou, Y, 2015). Saat ini, pendekatan Pengobatan Pelengkap dan Alternatif (CAM) telah didukung oleh studi klinis dan meta analisis untuk menurunkan tekanan darah dan meningkatkan efek gejala. Herbal adalah salah satu cara untuk menurunkan tekanan darah, atau hipertensi adalah pengobatan komplementer tanpa efek samping (Oktavia, I. E., \& Junaid, J2017)

Gaya hidup yang buruk dan rendahnya asupan buah dan sayuran dapat menjadi faktor risiko tekanan darah tinggi. Oleh karena itu, memperbanyak konsumsi buah dan sayur dapat menjadi pencegahan terhadap hipertensi dan penyakit kardiovaskular. Studi epidemiologi telah menunjukkan kelompok makanan tertentu seperti sayuran berdaun hijau dapat mencegah tekanan darah tinggi dan juga memiliki perlindungan paling signifikan terhadap penyakit jantung koroner dan risiko stroke iskemik (Bonilla Ocampo, 2018).

Pada penelitian ini bahwa ada pengaruh yang signifikan dengan pemberian rebusan daun seledri terhadap tekanan darah sistol dan diastol. Hal ini dapat dilihat dari perubahan penurunan tekanan darah sistolik sebelum diberikan rebusan daun seledri sebesar 18.75 sedangkan sistol sebesar $14.85 \%$.

Penelitian ini menjadi efektif menurunkan tekanan darah karena Apium graveolens atau seledri, digunakan dalam pengobatan tradisional sebagai agen anti hipertensi, mengandung senyawa kimia seperti apiin, apigenin, isoquercitrin, dan sesquiterpene (Rumiyanti, Rumiyati et al 2016). Kandungan apigenin yang berperan sebagai antagonis kalsium memiliki efek vasodilatasi. Selain itu seledri mengandung $n$ - butylphthalide (NBP) sebagai salah satu kandungan utama, yaitu senyawa berminyak dan tidak berwarna pada seledri. Kandungan minyakpada seledri memainkan peran penting dalam efek antihipertensi dari ramuan ini (Nurwahidah, N., \& Jubair, J,2019)

Beberapa penelitian telah melaporkan bahwa NBP memiliki efek diuretik pada tikus. Dengan demikian, efek diuretik dapat menjadi salah satu mekanisme antihipertensi pada biji seledri. Senyawa 3-n-butylphthalide dalam seledri dapat menurunkan konsentrasi hormon stres sehingga pembuluh darah kembali melebar dan 
mengendurkan lapisan otot polos pembuluh darah (Siska S, 2018).

Menurut kajian peneliti, penelitian ini dapat memberikan efek pada penurunan tekanan darah karena ada beberapa faktor resiko terjadinya hipertensi yang sudah dikendalikan pada penelitian ini seperti IMT, tidak merokok, jenis kelamin dan adanya observasi terhadap jenis makanan yang boleh dan tidak dikonsumsi selama penelitian. Selama proses penelitian, para responden menjalankan aturan dan prosedur dalam penelitian dengan baik dan dengan pengawasan dari para enumerator di lapangan.

Dengan mengkonsumsi 8 batang daun seledri selama 1 minggu dapat menurunkan tekanan darah menjadi $18.75 \%$ karena di dalam daun seledri banyak mengandung magnesium, ptalides, apingenin, kalium dan asparagin yang akan mengkontrol pembuluh darah untuk berkontraksi dan relaksasi sehingga tidak terjadi penyempitan pada pembuluh darah serta membantu proses diuretik dan mengandung senyawa penenang berupa ptslides yang akan mengkontrol aktivutas pembuluh darah.

\section{KESIMPULAN}

Hasil penelitian ini menunjukkan bahwa pemberian rebusan seledri (Apium Graveolens) efektif dalam menurunkan tekanan darah sistol dan diastol pada hipertensi ringan sebanyak $200 \mathrm{ml}$ selama 1 minggu dan diperoleh sebesar $18.75 \%$ dan $14.85 \%$ dengan nilai $p$ value 0.00 dan 0.001 .

Disarankan kepada para bidan dan masyarakat untuk dapat menerapkan dan mensosialisasikan terapi komplementer dengan memanfaatkan rebusan seledri kepada wanita menopause untuk menurunkan tekanan darah pada kasus hipertensi ringan.

Penelitian Sohrabi 2020 menyatakan bahwa ada pengaruh konsumsi seledri menurunkan kontraksi dalam cairan ekstraseluler otot polos pembuluh darah

\section{DAFTAR PUSTAKA}

Anjos, P. J., Lima, A. O., Cunha, P. S., De Sousa, D. P., Onofre, A. S., Ribeiro, T. P., ... \& Santos, M. R. (2013). Cardiovascular effects induced by linalool in normotensive and hypertensive rats. Zeitschrift für Naturforschung $C$, 68(5-6), 181-190.

Arie, N. N. M., Muntamah, U., \& Trimawati, T. (2014). Pengaruh Pemberian Air Rebusan Seledri Pada Lansia Penderita Hipertensi Di Dusun Gogodalem Barat. Jurnal Keperawatan Komunitas, 2(1), 4651.

Bogdanski, P., Suliburska, J., Szulinska, M., Stepien, M., Pupek-Musialik, D., \& Jablecka, A. (2012). Green tea extract reduces blood pressure, inflammatory biomarkers, and oxidative stress and improves parameters associated with insulin resistance in obese, hypertensive patients. Nutrition research, 32(6), 421-427.

Bomfim, G. H. S., Musial, D. C., Miranda-Ferreira, R., Nascimento, S. R., Jurkiewicz, A., Jurkiewicz, N. H., \& de Moura, R. S. (2019). Antihypertensive effects of the Vitis vinifera grape skin ( $\mathrm{ACH} 09)$ extract consumption elicited by functional improvement of $P 1 \quad(A 1)$ and $P 2$ $(\mathrm{P} 2 \mathrm{X} 1)$ purinergic receptors in diabetic and hypertensive rats. PharmaNutrition, 8, 100146.

Bonilla Ocampo, D. A., Paipilla, A. F., Marín, E., Vargas-Molina, S., Petro, J. L., \& Pérez-Idárraga, A. (2018). Dietary nitrate from beetroot juice for hypertension: a systematic review. Biomolecules, 8(4), 134.

Kemenkes, R. I. (2018). Hasil Utama Laporan Riskesdas 2018. Jakarta: 
Kementerian Kesehatan Republik Indonesia.

Moghadam, Maryam Hassanpour, Mohsen Imenshahidi, and Seyed Ahmad Mohajeri. "Antihypertensive effect of celery seed on rat blood pressure in chronic administration." Journal of medicinal food 16, no. 6 (2013): 558-563.

Niaz,

$$
\text { K. (2013). }
$$

Antihyperglycemic/hypoglycemic effect of celery seeds (ajwain/ajmod) in streptozotocin induced diabetic rats. Journal of Rawalpindi Medical College, 17(1), 134-137.

Nurwahidah, N., \& Jubair, J. (2019). Pengaruh Penggunaan Rebusan Seledri terhadap Penurunan Tekanan Darah pada Penderita Hipertensi di Wilayah Kerja Puskesmas Cenggu Tahun 2018. Bima Nursing Journal, 1(1), 43-49

Oktavia, I. E., \& Junaid, J. (2017). Pengaruh Pemberian Air Rebusan Seledri (Apium Graveolens) terhadap Penurunan Tekanan Darah Sistolik dan Diastolik Penderita Hipertensi di Wilayah Kerja Puskesmas Puuwatu Kota Kendari Tahun 2016. (Jurnal Ilmiah Mahasiswa Kesehatan Masyarakat), 2(6).

Pu, D., Tan, R., Yu, Q., \& Wu, J. (2017). Metabolic syndrome in menopause and associated factors: a metaanalysis. Climacteric, 20(6), 583591.

Rumiyati, Rumiyati, et al. "Antihypertensive Testing of Combination of Apium Graveolans L., Orthosiphon Stamineus Benth., and Morinda Citrifolial Extract. on Normotensive and Hypertensive Sprague Dawley Rats." Majalah Obat Tradisional (Traditional Medicine Journal) 21.3 (2016): 149-156.

Santoro, N., \& Johnson, J. (2019). Diagnosing the onset of menopause. Jama, 322(8), 775776.

Saputra, O., \& Fitria, T. (2016). Khasiat Daun Seledri (Apium graveolens) Terhadap Tekanan Darah Tinggi
Pada Pasien Hiperkolestrolemia. Jurnal Majority, 5(2), 120-125.

Siska, S., Munim, A., Bahtiar, A., \& Suyatna, F. D. (2018). Effect of Apium graveolens Extract Administration on the Pharmacokinetics of Captopril in the Plasma of Rats. Scientia pharmaceutica, 86(1), 6.

Sohrabi, F., Niazmand, S., Mahmoudabady, M., \& Niazmand, M. J. (2020). The vasodilatory effect of Apium graveolens L (celery) seed in isolated rat aorta: The roles of endothelium, calcium and potassium channels. Avicenna Journal of Phytomedicine.

Xiong, X. J., Wang, P. Q., Li, S. J., Li, X. K., Zhang, Y. Q., \& Wang, J. (2015). Garlic for hypertension: A systematic review and metaanalysis of randomized controlled trials. Phytomedicine, 22(3), 352361.

Yusuf, N., Anugerah, D. E., \& Adiani, F. (2017). Pengembangan Alat Deteksi Resiko Kehamilan Berbasis Web Sebagai Sistem Pencatatan Pelaporan Bagi Bidan. Jurnal Riset Kesehatan, 6(2), 55-61.

Zhou, Y., Zhou, X., Guo, X., Sun, G., Li, Z., Zheng, L., ... \& Sun, Y. (2015). Prevalence and risk factors of hypertension among pre-and postmenopausal women: a crosssectional study in a rural area of northeast China. Maturitas, 80(3), 282-287

Zhu, J., Zhang, Y., \& Yang, C. (2015). Protective effect of 3-nbutylphthalide against hypertensive nephropathy in spontaneously hypertensive rats. Molecular Medicine Reports, 11(2), 1448-1454. 